\title{
Research Note: Nutrient Evaluation of Compost and Vermicast Produced Through On-site Production Technique
}

\author{
Feliciano G. Sinon and Mark D. Atanasio \\ National Abaca Research Center, Visayas State University, \\ Baybay City, Leyte, 6521-A, Philippines.
}

\section{ABSTRACT}

This study, evaluates the process flow of nutrient from raw materials to compost to vermi fertilizer, and to assess the possibility of on-site organic fertilizer production technique.

Four different types of weeds such as Cogon (Imperata cylindrica), Hantutuknaw (Melastoma malabaticum), Hagunoy (Chromolaena odorata) and Bugang (Saccharum spontaneum) were collected in the project site of Guinsangaan, Inopacan, Leyte. These were shredded (using the mobile Plant Power Shredder) and placed inside a $1 \mathrm{~m} \times 1 \mathrm{~m} \times 1 \mathrm{~m}$ black plastic screen $(9$ mesh per $\mathrm{cm}^{2}$ ). The materials were allowed to decompose simulating the field condition. A 3/7 parts of chicken manure, 3/7 parts of soil taken from the project area and $1 / 7$ parts of the compost were mixed together inside the screen container (approx $1 / 2 \mathrm{~m}^{3}$ mixture). Three hundred grams of night crawler vermi were placed inside the container with the mixture. Each plastic screen was also placed inside the bin with silk screen (approx 200 mesh) bottom which were laid flat in the shaded and moist area.

The temperatures inside the bin ranged from $23{ }^{\circ} \mathrm{C}$ to $30{ }^{\circ} \mathrm{C}$ which were conducive for the growth of the worms. The Night Crawler thrived and grew in the open field condition - the weight of the stocked worms increased by $3.33 \%$ to $16.67 \%$.

NPK contents of the vermicast from the different bedding materials were more or less similar, although initially, these were obviously different. Hagonoy composts which was abundant in the marginal uplands was $2.5 \%$ higher in N compared to Cogon, Bugang and Hantutuknaw.

Keywords: organic fertilizers, vermicomposting, on-site, night crawler vermiworms, NPK

Correspondence : F.G. Sinon Address: National Abaca Research Center, Visayas State University, Baybay City, Leyte, 6521-A, Philippines Email: fgsinon@yahoo.com

DOI: 10.32945/atr36s15.2014 


\section{INTRODUCTION}

People in the Philippines are now getting aware of the negative effects of chemical based fertilizers to health. Thus, organically produced farm products are now becoming a fad to health conscious people and a commercial goal of most farmers in the country. To produce organic farm products, the source of nutrients for the farm crops should be from organic fertilizer.

Organic fertilizer, which is derived from biologically decomposed organic materials, is known to improve soil fertility and enhance crop production. One process of producing organic fertilizers that is much superior to other composting materials is the vermicomposting-using digestive action of worms to produce humus-like material known as vermicast (Munroe, 2004). Local Government Units (LGUs) and other NonGovernment Organizations (NGOs) are now promoting the centralized system of organic fertilizer production through pit and bed methods in shed houses. Raw materials have to be transported by the constituents to the processing center where these are shredded and decomposed. Other method described by Tindell (2010) is through bin, which is potential for on-site production.

Commercial scale production of organic fertilizer either through composting or vermi-composting has been applied successfully in different countries of the world. However, it has not yet been proven to be effective in our country. This is because commercial production requires higher capital investment due to some equipment outlay such as windrow turner, mixer, plant shredder, etc. According to Munroe (2004), vermicomposting is easy provided that the worms have hospitable living environment, food source, adequate moisture, adequate aeration and protection from extreme temperatures.

In the marginal upland areas, the approach therefore is to produce the fertilizer during unproductive season, when rain water for irrigation is not available and planting is done during rainy season, which is also timely for compost to be mature and ready for use.

In order to achieve this approach of on-farm, village-scale production system, development of farm implements suited for village-scale application is necessary. Moreover, some raw materials may contain toxic substances that may kill vermi-worms, and nutrients inappropriate for the intended crop to be grown, thus nutrient analysis of the available raw materials is necessary, to know its effect on the worms and to the end 
Nutrient Evaluation of Compost and Vermicast

products.

Thus, this study was conducted to evaluate the nutrient contents (NPK) of compost and vermicast produced through on-site production technique.

\section{MATERIALS AND METHODS}

The only source of raw materials for the production of organic fertilizer on-site are those which are available in the field. In this study, the samples were taken at the project site of Guinsangaan, Inopacan, Leyte which is located at $\mathrm{N} 10.48311^{\circ}$ and $\mathrm{E} 124.76139^{\circ}$ or $8 \mathrm{~km}$ East of Inopacan proper with an elevation of about $132 \mathrm{~m}$ above sea level. Most of the raw materials available in the area were weeds such as Cogon (Imparata cylindrica) (40\%), Bugang (Saccharum spontaneum) (30\%), Hantutuknaw (Melastoma malabaticum) (20\%), and Hagunoy (Chromolaena odorata) $(10 \%)$. Farmers in this locality usually plant sweet potato, cassava, and corn. Only few coconut trees were available and the area was about 90 to $95 \%$ open field.

\section{Collection of Materials from the Project Site}

To be able to monitor and control the environmental conditions of the experiment, the samples were collected manually from the field at about 3 sacks each of the four common weeds. These were brought to VSU, Baybay and were prepared for shredding in the following day. The materials had about $30-50 \%$ moisture content.

\section{Plant Shredding using Mobile Plant Power Shredder}

To hasten the process of decomposition, the collected samples were shredded into $2 \mathrm{~mm}$ to $2 \mathrm{~cm}$ long plant particles using the mobile type Plant Power Shredder developed at the National Abaca Research Center, VSU, Baybay City, Leyte. The mobile plant power shredder can be hitched directly into the 2 wheeled hand tractor or can be hitched into a four wheel car as a trailer.

For easy collection of the shredded materials, a 1 meter by 1 meter by 1 meter plastic net bag ( 9 mesh per $\left.\mathrm{cm}^{2}\right)$, was placed at the spout of the machine, to collect directly the shredded materials. The bag was temporarily strengthened using a foldable frame made from $1 / 2$ inch by $1 / 8$ inch flat steel bar. 


\section{Open Field Partial Decomposition}

Shredded materials contained in the $1 \mathrm{~m}$ by $1 \mathrm{~m}$ by $1 \mathrm{~m}$ net bag were allowed to decompose naturally under open field condition. Ocassionally, these were flipped over to balance exposure of the materials to the environment. After 1 and $1 / 2$ months, a partial decomposition of the materials were noticed based on its texture (almost crumbling), color (changing from green to pale or brownish), and hardness (fluffy and soft).

\section{Vermi composting}

A 3/7 parts of chicken manure, $3 / 7$ parts of soil taken from the project area and $1 / 7$ parts from the partially compost material were mixed together inside the screen container (approx. $1 / 2 \mathrm{~m}^{3}$ mixture) to serve as beddings for the Night Crawler vermi-worm. Table 1 shows the weights of the beds used in this experiment. The components were placed first in the black plastic screen sack and then to the bin of silk screen bottom (approx. 200 mesh) for the collection of vermicast materials. The silkscreen provided proper aeration and prevented the worms from escaping. Each bin was stocked with $300 \mathrm{~g}$ worms bought from the Regional Vermicompost Vermimeal Production Project in VSU. Coconut and banana leaves were used as temporary cover to prevent extreme rise in temperatures. Water content was maintained daily-at point just enough to be squeezed by fingers (WRSU, 2010).

Table 1. Weight of the bedding components for vermi-composting

Bedding Components, kg

\begin{tabular}{cccc} 
Weeds & Compost & Soil & $\begin{array}{c}\text { Chicken } \\
\text { Dung }\end{array}$ \\
\hline Hantutuknaw & 5 & 15 & 15 \\
Hagonoy & 4 & 12 & 12 \\
Bugang & 5 & 15 & 15 \\
Cogon & 3 & 9 & 9 \\
\hline
\end{tabular}


Nutrient Evaluation of Compost and Vermicast

Nutrient Analysis

Before the start of the experiment, samples from different bedding materials such as soil from the project site, partially compost materials, and chicken manure, were submitted for NPK analysis at the VSU Central Analysis Service Laboratory located at the PhilRootcrops at VSU, Baybay City, Leyte. Another set of samples of about $300 \mathrm{~g}$ each were taken from each vermicast materials after the vermi casting experiment was terminated. These were also submitted for NPK analysis.

The analysis serves as the basis in coming up with a more direct to the point recommendations on the type of crop to be grown in the project site and also to recommend the type of fertilizer to suplement the lacking nutrient in the area.

\section{Vermi Night Crawler Survival Analysis}

Termination of the vermi casting was done after 25 days when it was observed that most of the partially compost materials which were sources of food for the worms were almost exhausted. Worms from each bin were immediately collected and weighed to determine their weight difference and health conditions.

\section{RESULTS AND DISCUSSION}

\section{Vermi Environment and Temperature}

For thousand of years, worms survive in an environment under the soil without the influence of man. Thus, in principle, vermi worms have the ability to thrive easily in a very conducive environment. In this experiment, the vermi worms were allowed to survive inside the plastic screen bag with the bedding materials in a bin with silk screen bottom. To reduce the temperature inside the bin, these were covered with banana and coconut leaves. With this condition, it was observed that the worms thrive at temperature ranging from $23{ }^{\circ} \mathrm{C}$ to $30^{\circ} \mathrm{C}$ (Table 2).

\section{Potential for on-site production system}

On-site production of organic fertilizer has great potential to reduce the cost and significantly increase its production. Its usefulness was 
evaluated in terms of its effect on NPK contents, tracing from its raw materials used as beddings to its final vermicast product.

Table 2. Bin temperatures at each substrate

\begin{tabular}{lcccccc}
\hline \multirow{2}{*}{ Day } & \multirow{2}{*}{ Time } & \multicolumn{5}{c}{ Temperature at bins, ${ }^{\circ} \mathrm{C}$} \\
\cline { 3 - 7 } & & Hagonoy & Hantutuknaw & Cogon & Bugang & AVERAGE \\
\hline \multirow{3}{*}{$\mathrm{A}$} & 9:00 AM & 23 & 26 & 26 & 26 & 25 \\
& 12:00 Noon & 24 & 33 & 32 & 29 & 30 \\
& 3:00 PM & 25 & 30 & 30 & 29 & 29 \\
$\mathrm{~B}$ & 9:00 AM & 28 & 28 & 31 & 25 & 28 \\
& 12:00 Noon & 29 & 29 & 34 & 23 & 29 \\
& 3:00 PM & 28 & 28 & 31 & 24 & 28 \\
$\mathrm{C}$ & 9:00 AM & 22 & 22 & 24 & 27 & 24 \\
& 12:00 Noon & 29 & 32 & 27 & 32 & 30 \\
& 3:00 PM & 26 & 26 & 26 & 23 & 25 \\
$\mathrm{D}$ & 9:00 AM & 23 & 23 & 24 & 23 & 23 \\
& 12:00 Noon & 29 & 29 & 30 & 32 & 30 \\
& 3:00 PM & 28 & 29 & 28 & 27 & 28 \\
\hline
\end{tabular}

Bedding Materials and NPKContents

Different materials have different chemical compositions and nutrient contents. It is a common knowledge that vermicast products have NPK contents depending on the type of food materials eaten by the vermi worms.

The undisturbed NPK contents of the materials used as beddings for the vermi worms are presented in Table 3. Hagunoy had higher nitrogen content of $2.5 \%$ than all the other materials. Chicken dung had also higher potassium and phosphorous contents. However, the NPK analysis of vermicast showed different results. All the vermicasts from different bedding materials produced similar NPK contents. Nitrogen content ranged from 1.3 to $1.5 \%$, Potassium at 0.2 to $0.3 \%$, and Phosphorous at 0.1 to $0.3 \%$ only. They results contradicted the common knowledge, which suggests that any type of bedding materials in the field could be a potential source of food materials for the vermi worms. Ghosh, Chattopadhyay and Banal (1999) reported a successful conversion of phosphorous from organic to inorganic or into a more available form. In this study, the vermi worms were effective in converting the food materials and digested the nutrients and released as a processed product with similar NPK nutrient contents.Ziegenfuss et al. (1991) used composting successfully at the fieldscale to decontaminate explosives-contaminated sediments, while Vig, et al. (2011); Khwairakpam and Bhargava; Suthar (2009) and Mba (1996) 
Nutrient Evaluation of Compost and Vermicast

used vermicomposting with Eisenia fetida to change toxic tannery, cassava peelings, and sewage sludge into nutrient rich manure.

Table 3. Initial NPK contents of the vermi bedding materials

\begin{tabular}{cccc}
\hline \multirow{2}{*}{ Component } & \multicolumn{3}{c}{ Total, \% } \\
\cline { 2 - 4 } & $\mathrm{N}$ & $\mathrm{P}$ & $\mathrm{K}$ \\
\hline Soil & 0.272 & 0.012 & 0.821 \\
Chicken dung & 1.666 & 0.147 & 1.305 \\
Hantutuknaw & 1.513 & 0.017 & 0.229 \\
Hagonoy & 2.501 & 0.018 & 0.126 \\
Bugang & 1.718 & 0.018 & 0.371 \\
Cogon & 1.456 & 0.017 & 0.155 \\
\hline
\end{tabular}

Table 4. NPK contents of the vermicasts from the different substrates

\begin{tabular}{cccc}
\hline Vermicasts & \multicolumn{3}{c}{ Total, \% } \\
\cline { 2 - 4 } & $\mathrm{N}$ & $\mathrm{P}$ & $\mathrm{K}$ \\
\hline & & & \\
Hantutuknaw & 1.394 & 0.2896 & 0.1425 \\
Hagonoy & 1.344 & 0.3016 & 0.1502 \\
Bugang & 1.394 & 0.2909 & 0.2925 \\
Cogon & 1.504 & 0.2141 & 0.2313 \\
\hline
\end{tabular}

Health and Survival of Night Crawler Vermi Worms

The health and survival of the vermi worms can be evaluated in terms of the weight it has gained after the experiment and the physical condition of the worms. However, since evaluation of the physical condition would require medical instruments and equipment which are not presently available, evaluation was based only on its weight gained.

During the monitoring period, it was observed that the presence of vermicasts were already perceptible inside each bin after a week. On the second week, presence of casts could already be observed outside the nets.

The vermi casting experiment was terminated after 25 days of monitoring. It was observed that the worms were able to grow inside the bin with good physical condition as observed by its shiny, vigorous and fat bodies (Figure 1). The weights of the worms before and during the termination are presented in able 5. Only the worms in the Hagonoy bin had decreased weight may be due to migration of worms to the other 
bin since there was a tear present in the silkscreen. Migration of the worm could be caused by two scenarios, 1) the worms did not like the available food inside the bin causing them to migrate to look for another source (WSRU, 2010), or 2) the termination of the experiment might be too late.

The worms may have consumed the partially composed raw material causing them to migrate and look for food. This can be explained by the small amount of the remaining raw materials in the bin. Considering that Hagonoy has high nitrogen content, this could be a good material for compost production. In the study of Edwards and Lofty (1982), they confirmed that population of earthworms increased significantly with the presence of organic and inorganic nitrogen in the soil. Plots receiving both inorganic and organic $\mathrm{N}$ had the largest populations of earthworms.

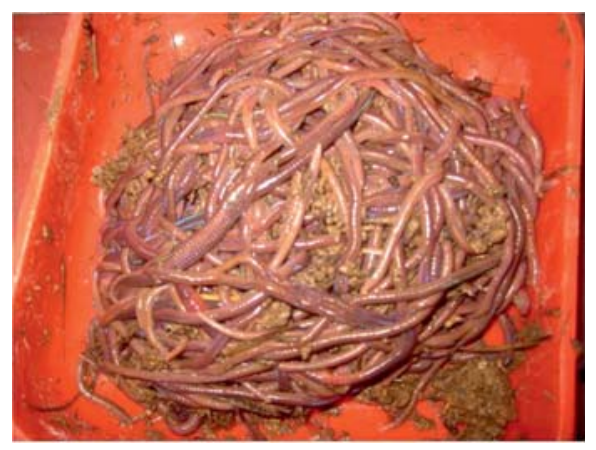

Figure 1. The vermi worms after 25 days

Table 5. Weight of the vermi worms before and after the experiment

\begin{tabular}{ccc}
\hline \multirow{2}{*}{ Bins } & \multicolumn{2}{c}{ Worms, Kg } \\
\cline { 2 - 3 } & Before & After \\
\hline Hantutuknaw & 300 & 340 \\
Hagonoy & 300 & 250 \\
Bugang & 300 & 310 \\
Cogon & 300 & 350 \\
\hline
\end{tabular}




\section{CONCLUSION}

Composting using Night Crawler vermi worms is higly possible in an open field condition due to the natural characteristics of worms to survive in the harsh environment under the soil. The use of plastic screen bag in a bin with silk screen bottom can be used to contain the worms and collect the vermi cast successfully. The worms were healthy and grew in weight after 25 days inside the bin with temperature ranging from $23^{\circ} \mathrm{C}$ to $30^{\circ} \mathrm{C}$.

The different bedding materials (Cogon, Hantutuknaw, Hagunoy and Bugang) although having different NPK contents, have vermi cast products which have similar NPK contents. This study concludes that the Night Crawler worms were effective in converting the different organic materials into casts with NPK contents of similar values.

\section{RECOMMENDATION}

A follow up study shall be conducted using screens that are more durable to prevent the worms from boring holes and migrate.

On-site production using vermi worms shall be tried in the actual field condition using different bedding materials to assess its practical application.

\section{ACKNOWLEDGMENT}

The financial support from the Philippine Higher Education Research Network (PHERNET) was highly appreciated.

\section{REFERENCES}

EDWARDS, C. A. and J.R. LOFTY. 1982. Nitrogenous fertilizers and earthworm populations in agricultural soils. Soil Biology and Biochemistry 14(5): 515-521.

GHOSH, M., G.N. CHATTOPADHYAY and K. BARAL. 1999. Transformation of phosphorus during vermicomposting. Bioresource Technology 69(2): 149-154.

KHWAIRAKPAM, M. and R. BHARGAVA. 2009. Vermitechnology for sewage sludge recycling.Journal of Hazardous Materials 161(23): 948-954. 
MBA, C. C. 1996. Treated-cassava peel vermicomposts enhanced earthworm activities and cowpea growth in field plots. Resources, Conservation and Recycling 17(3): 219-226.

MUNROE G. 2004. Manual of On-Farm Vermicomposting and Vermiculture. Organic Agriculture Centre, Canada.

SUTHAR, S. 2009. Vermistabilization of municipal sewage sludge amended with sugarcane trash using epigeic Eisenia fetida (Oligochaeta). Journal of Hazardous Materials 163(1): 199-206.

TINDELL J.P. 2010. How to Vermicompost at Home or Work. Department of Parks and Recreation, Sacramento, CA.

VIG, A. P., J. SINGH, S.H. Wani and S.S. DHALIWAL. 2011. Vermicomposting of tannery sludge mixed with cattle dung into valuable manure using earthworm Eisenia fetida (Savigny). Bioresource Technology 102(17): 7941-7945.

WSRU. 2010. Vermiculture Program Manual of Operations. Washington State Reformatory, USA.

ZIEGENFUS P.S., R.T. WILLIAMS and C.A. MYLER 1991. Hazardous materials composting. Journal of Hazardous Materials 28(12): 91-99. 